\title{
COLUMN
}

\section{Blurring en blending niet hetzelfde als work-life balance}

\author{
Pascale Peters ${ }^{*}$
}

In mijn proefschrift The vulnerable hours of leisure (Peters, 2000) reflecteerde ik op de veranderende relatie tussen werk en privé in de naoorlogse periode. In tegenstelling tot de belofte van de 'vrijetijdsmaatschappij' (Dumazedier, 1967), die door de toegenomen arbeidsproductiviteit binnen handbereik leek, nam ondanks formele arbeidstijdverkorting de druk op de vrije tijd toe. Oorzaken hiervan waren de toegenomen arbeidsparticipatie van vrouwen, de nieuwe eisen die werden gesteld aan opvoeding (waaronder het nieuwe vaderschap) en consumptie, én de intensivering van het betaald werk in het licht van de toegenomen internationale concurrentie. In diezelfde periode nam de vraag naar flexibiliteit voor de werkgever toe, maar ook de behoefte onder werknemers aan autonomie en tijdruimtelijke flexibiliteit, persoonlijke groei en uitdaging in het werk.

Mijn huidige interesse in onderzoeksthema's zoals telewerken en Het Nieuwe Werken, werk-privébalans, en de verschuivende en (half)doorlatende grenzen tussen het werk- en het privédomein, sluiten aan bij de bovengenoemde trends. Telewerken, ofwel het werken op afstand van de werkgever of opdrachtgever met behulp van ICT, is een concept dat in de jaren zeventig tijdens de oliecrisis werd geïntroduceerd om de mobiliteitsbehoefte en de hiermee samenhangende milieuschade te reduceren. In de crisis van de jaren tachtig werd telewerken gebruikt om werkprocessen efficiënter in te richten en kosten te besparen. In de krappe arbeidsmarkt van de jaren negentig was telewerken voornamelijk een secundaire arbeidsvoorwaarde, afgedwongen door werknemers met een sterke arbeidsmarktpositie die behoefte hadden aan een betere werk-privébalans of geconcentreerd werken. Aan het begin van deze eeuw leek telewerken compleet van de agenda te zijn verdwenen, maar na het verschijnen van de white paper 'The New World of Working' van Microsoft CEO Bill Gates (2005) geniet het concept onder de naam Het Nieuwe Werken (HNW) vooral sinds de jaren daarna opvallend veel maatschappelijke en wetenschappelijke aandacht.

Gates presenteerde een fundamenteel 'nieuwe visie op werk'. Werk zou met behulp van technologie efficiënter en effectiever kunnen worden georganiseerd, maar tegelijkertijd ook gepaard kunnen gaan met meer arbeidsplezier en zingeving. De opkomst en noodzaak van een nieuwe manier van werken waarin elementen van het vrijetijdsdomein, zoals plezier en zeggenschap, zouden zijn overgeslagen naar het arbeidsdomein, waren al eerder door vooraanstaande

* Pascale Peters is verbonden aan de Radboud Universiteit Nijmegen, e-mailadres: p.peters@fm.ru.nl. 
wetenschappers aangekondigd en bepleit (Bell, 1974; Drucker, 2000; Galbraith, 1958). Maar blijkbaar vormde het samenspel van ontwikkelingen na 2005 pas dé window of opportunity om telewerken en HNW, zowel bij overheid, werkgevers als werknemers, (opnieuw) onder de aandacht te brengen. De motieven die nu worden genoemd, lijken sterk op die uit het verleden (mobiliteit en milieu; efficiency en bezuinigingen; krapte op de arbeidsmarkt en werk-privébalans). Meer dan telewerken wordt HNW echter gedreven door de sterk toegenomen concurrentie en de noodzaak om werknemers te engageren en te motiveren om zich in te zetten voor de strategische doelen van de organisatie.

Anders dan telewerken, dat vaak betrekking heeft op individuele afspraken tussen een individuele werknemer en zijn of haar leidinggevende, vraagt HNW om een radicale organisatiebrede cultuurverandering die werknemers stuurt in de richting van het gewenste gedrag. In mijn onderzoek verwijst HNW tevens naar een HRM-systeem dat bestaat uit een bundel van praktijken: een hoge mate van professionele autonomie en verantwoordelijkheid voor het tijdig bereiken van resultaten; tijd-ruimtelijke flexibiliteit; en (virtuele) samenwerking (Peters et al., 2011). Vrijheid en verantwoordelijkheid impliceert tevens dat werknemers zich proactief en innovatief dienen te gedragen. De nieuwe manier van werken maakt het mogelijk om altijd, overal, en met verschillende partners (virtueel) samen te werken. In welke mate de werknemer van deze mogelijkheden gebruikmaakt, hangt af van de behoefte van de individuele werknemer, maar ook van die van de organisatie en de klant.

In het huidige debat wordt de met HNW geassocieerde flexibiliteit vaak gelijkgesteld aan work-life balance. Juist daarin schuilt een gevaar. Het collectief loslaten van de traditioneel sociaal geconstrueerde grenzen tussen werk en privé maakt het mogelijk om over eigen grenzen heen te gaan, vooral wanneer de verantwoordelijkheid voor het behalen van targets en strakke deadlines door werknemers sterk wordt gevoeld. De mogelijkheid om werk en privéactiviteiten meer door elkaar heen te laten lopen (blurren) of te vermengen (blenden) kan ertoe leiden dat werknemers die werk en privé sterker integreren, een verstoorde werk-privébalans ervaren, bijvoorbeeld omdat zij werken op tijdstippen die voorheen gereserveerd waren voor gezinsactiviteiten.

Het bovenstaande wordt bevestigd in een recente studie binnen vier organisaties waarin hoogopgeleide kenniswerkers in hoge mate flexibel kunnen werken naar tijd en plaats, zelf verantwoordelijk zijn voor de manier waarop ze hun rol binnen de organisatie vormgeven, en worden afgerekend op hun prestaties (Peters et al., in voorbereiding). De studie laat zien dat de manier waarop werknemers hun grenzen tussen werk en privé bewaken of 'managen' (variërend van een hoge mate van segmentatie tot een hoge mate van integratie), niet samenhangt met het ervaren van werk-privéconflict. Wel blijkt een hoge mate van integratie samen te gaan met het ervaren van minder positieve spill-over van privé naar werk. Opvallender is echter dat één op de vier werknemers in deze studie werk en privé meer integreerde dan gewenst (slechts één respondent segmenteerde meer dan hij of zij zou willen). Deze discrepantie ging gepaard met meer disbalans, vooral wanneer werknemers meer verantwoordelijkheid namen voor het behalen van de gestelde werkdoelen. 
De vrijetijdsmaatschappij in termen van het vertalen van productiviteitswinst door de inzet van ICT in het werk naar meer vrije tijd voor allen is niet uitgekomen. Wel werd in de naoorlogse periode de basis gelegd voor Het Nieuwe Werken. Vrijetijdselementen zijn steeds meer het arbeidsdomein binnengedrongen. Werken is plezieriger geworden en een nieuwe manier van organiseren heeft de zeggenschap van werknemers over waar en wanneer zij kunnen werken vergroot. Het realiseren van de missie van HNW staat of valt echter met het creëren van de juiste cultuur waarin werknemers op een verantwoorde wijze gebruik kunnen maken van de mogelijkheden die HNW biedt, zoals het blurren en blenden van werk en privéactiviteiten. In de context van HNW kan integratie echter gemakkelijk doorschieten en moet dan ook niet worden verward met work-life balance.

\section{Literatuur}

Bell, D. (1974). The coming of post-industrial society. New York: Harper Books.

Drucker, P. (2000). Management uitdagingen in de 21e eeuw. Amsterdam: Business Contact.

Dumazedier, J. (1967). Towards a society of leisure. New York: The Free Press.

Galbraith, J.K. (1958). The affluent society. Harmondsworth: Penguin.

Gates, B. (2005). The New World of Work. www.microsoft.com/mscorp/execmail/ 2005/05-19newworldofwork.mspx.

Peters, P. (2000). The vulnerable hours of leisure: New patterns of work and free time in the Netherlands, 1975-95. Amsterdam: Thela Thesis.

Peters, P., Bruijn, T. de, Bakker, A. \& Heijden, B. van der (2011). Plezier in Het Nieuwe Werken. Tijdschrift voor HRM. Themanummer Nieuwe vormen van werken, 14(1), 31-47.

Peters, P., Heijden, B. van der \& Berg, L. van den (in voorbereiding). Blurring and blending: No guarantee for work-life balance. 